\title{
The Effect of Social Media Advertising and Face-to-Face Sales on Purchase Intention for Customized Products (Case Study of Puncak Jaya Furniture)
}

\author{
Fasta Biqul Khairolt \\ Master of Management, Sriwijaya University, Palembang, Indonesia \\ Corresponding author email: fastabiqulkhairot1709@gmail.com
}

\section{Sulastri}

Lecturer of Magister Management, Economic Faculty, Sriwijaya University, Palembang, Indonesia

Email: sulastri2310@gmail.com

\author{
Zakaria Wahab \\ Lecturer of Magister Management, Economic Faculty, Sriwijaya University, Palembang, Indonesia \\ Email: zkwahab01@gmail.com \\ Marlina Widiyanti \\ Lecturer of Magister Management, Economic Faculty, Sriwijaya University, Palembang, Indonesia \\ Email: marlinawidiyanti68@yahoo.co.id
}

\begin{abstract}
This research was conducted to show the effect of social media advertising and face-to-face sales on the buying interest of customized products (Puncak Jaya Furniture Case Study). The data source used is a questionnaire. The population in this study came from the social media followers of Instagram Puncak Jaya Furniture, with as many as 24,300 followers. The sample used in this study were followers who had the desire and bought products at Puncak Jaya Furniture from December 1, 2020, to January 17, 2021, as many as 30 people. The questionnaire was created using the google form application and distributed via WhatSapp message. The data collection method uses the linear regression method. This study indicates that social media advertising variables have a positive and significant impact on purchase intention, while face-to-face sales variables also have a positive but insignificant impact on purchase intention. The implication of this research is to increase knowledge related to buying Interest seen from the factors of social media advertising and face-to-face sales. For related parties and further research, it is hoped that this research can be used as a reference and reference for related variables. Keywords---face to face sales, purchase interest, social media advertising.
\end{abstract}

\section{Introduction}

According to Kotler (2021) buying Interest arises after receiving stimulation from a product that he sees; there is an interest in trying the product until finally the desire to buy to have it arises. Schiffman \& Kanuk (2020), explain that external influences, awareness of needs, product introduction, and evaluation of alternatives can lead to consumer buying interest. Advertising initially through conventional advertising, namely using newspaper print media marketing, began to be abandoned. According to Aldily (2017), there are many developments in online marketing media today. Starting from online shops, social media, marketplaces, and several forums usually used as discussion places, they can also be used for buying and selling. Home furniture, which was initially available in finished form, changed the model to a knockdown system. This is one of the reasons why the public increasingly favors custom minimalist furniture. The advantages mentioned above must be explained and explained by the seller to consumers as 
best as possible to create Interest in buying products at Puncak Jaya Furniture, one of which is through social media advertising and face-to-face sales (Szolnoki \& Hoffmann, 2013; Alalwan et al., 2017; De Vries et al., 2012). Advertising initially through conventional advertising, namely using newspaper print media marketing, began to be abandoned. Global Information and Measurement Company Nielsen released its research results that in Indonesia, currently, there are more readers of digital online media than print media. According to Reily (2018), more digital media readers in Indonesia are currently more than print media. People have started leaving newspapers to get information. With the abandonment of mass media such as newspapers, the use of newspapers as a means of promotion has decreased.

After social media advertising, the promotion mix focuses on personal selling. According to Kotler (2021), faceto-face selling (personal selling) is the most cost-effective tool at a later stage of the buying process, especially in building buyer's preferences, beliefs, and actions. Another factor of buying Interest besides the attractiveness of advertising is Face-to-Face Sales. Purchase interest which one aspect of it is product needs (need arousal) as in-home equipment needs (Lafferty \& Goldsmith, 1999; Hausman \& Siekpe, 2009; Maxham III, 2001). Puncak Jaya Furniture offers the latest models of furniture for the needs of consumers' homes.

\section{Literature Study}

\section{Purchase interest}

According to Gibler \& Nelson (2003), purchase interest is the tendency of consumers to buy a brand or take actions related to purchases as measured by the level of consumers' likelihood of making a purchase. According to Kotler (2021), buying Interest arises after receiving stimulation from a product that he sees; there is an interest in trying the product until finally the desire to buy to have it arises. According to Sari and Kusuma, the dimensions of purchase intention are (1). Likely (2). Probable (3). Definitely

\section{Personal selling}

Personal selling must continue to be improved (Wahab et al., 2021). This is inseparable from the skills and expertise of salespeople or salespeople in persuading consumers to buy products. The definition of personal selling according to several marketing experts. According to Kotler (2021), face-to-face selling (personal selling), namely the oral presentation in a conversation with one or several potential buyers, makes a sale. According to Kotler (2021), faceto-face selling (personal selling) is the most cost-effective tool at a later stage of the buying process, especially in building buyer's preferences, beliefs, and actions. According to Sutisna (2002), face-to-face selling (personal selling) is a communication activity between producers represented by salespeople and potential consumers that involves thoughts and emotions, and of course, face-to-face.

\section{Social media advertising}

According to Hasan (2019), social advertising applies marketing knowledge, concepts, and techniques to increase social awareness and economic goals. To keep in mind, social networks may be used to build long-term relationships and customer networks, not to directly generate revenue, meaning that social media should be used as a marketing support activity to meet target customers (Solis \& Breakenridge, 2009; Wang et al., 2012; Subawa et al., 2020).

\section{Conceptual framework}

The conceptual framework is a logical relationship between theoretical foundations and empirical studies. The conceptual framework shows the influence between variables in research.

\section{Relationship between variables and hypothesis development}

H1: Social Media Advertising has a positive effect on product purchase interest in Puncak Jaya Furniture.

H2: Face-to-face sales have a positive effect on product purchase interest at Puncak Jaya Furniture. 


\section{Research Method}

Research design

The research design used was explanative associative research. This is because this study aims to examine the causal relationship between the independent variables, namely Social Media Advertising (X1), Face-to-Face Sales (X2), and the dependent variable, namely, Purchase Interest (Y).

\section{Population, sample, and sampling technique}

The population in this study were followers of the social media Instagram www.Instagram.com, totaling 24.3 thousand followers.

\section{Sample and sampling techniques}

The number of samples was determined from this population, which focused on the Puncak Jaya Furniture Instagram social media account who bought Puncak Jaya Furniture products from December 1, 2020, to January 17, 2021, as many as 30 people

\section{Data collection methods}

In this study, data collection was carried out using a questionnaire. The data collection method is done by giving respondents a guide choice of answers related to social media advertising on consumer buying interest in Furniture products in Puncak Jaya Furniture.

\section{Validity test}

The validity test is carried out to determine whether the measuring instrument that has been made can be used to measure what they want to measure appropriately. Measure the validity of 3 variables, namely X1 Social Media Advertising, X2 Personal Selling, and Y Purchase interest as many as 30 respondents

\section{Reliability test}

Reliability means the level of trustworthiness of the results of a measurement. Measurements with high reliability, namely measurements that can provide reliable measurement results (reliable), were essential. The level of reliability is empirically indicated by a number called the reliability coefficient. The statistical test that can be used in determining the level of internal reliability of a measuring instrument is the Cronbach Alpha test using the help of the SPSS program

\section{Model feasibility test: F test}

A simultaneous significance test can be done by observing the significant value of $\mathrm{F}$ at the $\alpha$ level used (this study uses the $\alpha$ level of $5 \%$ ). The analysis is based on comparisons between the 0.05 significance values where the terms are as follows:

1) If the significance of $\mathrm{F}<0.05$, then $\mathrm{H} 0$ is rejected, which means that the research equation model is feasible.

2) If the significance of $\mathrm{F}>0.05$, then $\mathrm{H} 0$ is accepted; this equation model is not feasible.

\section{Coefficient of determination (R2)}

Find out how far the independent variable can explain the dependent variable; it is necessary to know the coefficient of determination or determination of the $\mathrm{R}^{2}$ value ranging from 0 - 1 , the closer to 1 the $\mathrm{R}^{2}$ value means the more significant the independent variable $(\mathrm{X})$ can explain the dependent variable $(\mathrm{Y})$. Analysis of the value of R-Square or $\left(\mathrm{R}^{2}\right)$ is used to determine the extent to which the independent variable (X) can explain the relationship between changes in the dependent variable (Y). The properties of R-Square are strongly influenced by the number of independent variables, where the more independent variables, the greater the R-Square value. 
Data analysis techniques

To prove whether there is a causal relationship between independent variables and related variables, the analysis tool to predict the value of the effect or more independent variables on one dependent variable is multiple linear regression. The multiple linear regression equation is formulated as follows:

$$
Y=a+b 1 \times 1+b 2 \times 2+e
$$

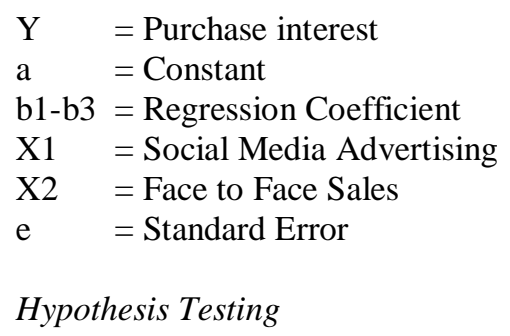

Hypothesis Testing

The hypothesis test used in this study is the partial test (t-test). The t-test shows whether the independent variables included in the model influence the dependent variable individually (partially).

The hypothesis in this test is:

Ho: $b i<0$. This means that there is no effect of the ith variable on the dependent variable.

Ha: bi>0. This means that the ith variable affects the dependent variable

\section{Discussion}

\section{Test results of research instruments}

Based on the research method described in Chapter III, the questionnaire results taken from 30 respondents were tabulated and processed using the SPSS version 26 statistical computer program to test the validity and reliability test.

\section{Validity test results}

Table 1

Validity test results

\begin{tabular}{ccccc}
\hline Indicator & Item & r-counting & r-table & Info \\
\hline Social Media Advertising (X1) & 1 & 0,493 & 0,361 & Valid \\
& 2 & 0,524 & 0,361 & Valid \\
& 3 & 0,400 & 0,361 & Valid \\
& 4 & 0,474 & 0,361 & Valid \\
& 5 & 0,601 & 0,361 & Valid \\
& 6 & 0,567 & 0,361 & Valid \\
& 7 & 0,398 & 0,361 & Valid \\
Face to Face Sales (X2) & 8 & 0,495 & 0,361 & Valid \\
& 9 & 0,578 & 0,361 & Valid \\
& 10 & 0,393 & 0,361 & Valid \\
& 1 & 0,432 & 0,361 & Valid \\
& 2 & 0,560 & 0,361 & Valid \\
& 3 & 0,406 & 0,361 & Valid \\
& 4 & 0,469 & 0,361 & Valid \\
& 5 & 0,550 & 0,361 & Valid \\
& 6 & 0,377 & 0,361 & Valid \\
& 7 & 0,608 & 0,361 & Valid \\
\hline
\end{tabular}




\begin{tabular}{lllll}
\hline Interests Buy (Y) & 1 & 0,634 & 0,361 & Valid \\
& 2 & 0,689 & 0,361 & Valid \\
& 3 & 0,600 & 0,361 & Valid \\
4 & 0,708 & 0,361 & Valid \\
& 5 & 0,642 & 0,361 & Valid \\
& 6 & 0,721 & 0,361 & Valid \\
\hline
\end{tabular}

Data source: Processed from questionnaires, 2021

Based on the table above, it is known that each indicator (item) in each variable of social media advertising, face-toface sales, and purchase interest has a result of r-count greater than r-table 0.361 so that the indicator (item) used in this research variable can be declared valid and can be used as items in data collection.

\section{Reliability test}

Table 2

Reliability test results

\begin{tabular}{lccccc}
\hline \multicolumn{1}{c}{ Indicator } & $\begin{array}{c}\text { Cronbach's } \\
\text { Alpha }\end{array}$ & Cutt Off & N of Case & N of Item & information \\
\hline Social Media Advertising $\left(\mathrm{X}_{1}\right)$ & 0,616 & $>0,60$ & 30 & 10 & Reliable \\
Face-to-Face Sales $\left(\mathrm{X}_{2}\right)$ & 0,735 & $>0,60$ & 30 & 7 & Reliable \\
Interests Buy(Y) & 0,738 & $>0,60$ & 30 & 6 & Reliable \\
\hline
\end{tabular}

Data source: Processed from questionnaires, 2021

Based on the results of the reliability test of the research variable instrument in the table above, the results of the reliability test for the independent variable of social media advertising (X1) and face-to-face sales (X2) show that the data obtained is reliable because the Cronbach's Alpha values are 0.616 and 0.735 . Furthermore, the reliability test results of the dependent variable buying interest $(\mathrm{Y})$ also show that the data obtained is reliable because the Cronbach's Alpha value is 0.738 .

\section{Normality test results}

The data normality test is carried out to determine whether the data obtained is usually distributed or not. The normality test carried out on the sample was carried out using the Kolmogorov-Smirnov test by setting the degree of confidence (a) at 5\% (Prayitno, 2019). The results of the normality test are in the table as follows:

Table 3

Normality test results

\begin{tabular}{lcccc}
\hline \multicolumn{1}{c}{ Test of Normality } & Sig. & & Kolmogorov- Smirnov & \\
Social Media Advertising (X1) & 0,2 & $>$ & 0,05 & Information \\
Face to Face Sales (X2) & 0,2 & $>$ & 0,05 & Normal \\
Purchase Interest (Y) & 0,39 & $>$ & 0,05 & Normal \\
\hline
\end{tabular}

Data source: Processed from questionnaires, 2021 


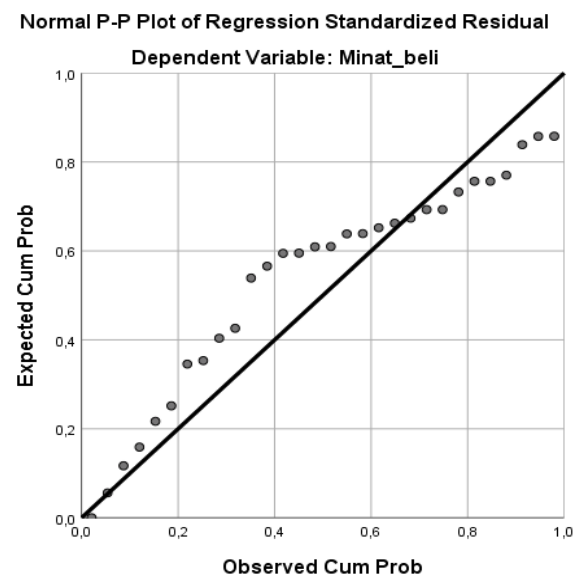

Figure 1. Normal P-P Plot of Regression Standardized Residual

The picture above shows that the data is usually distributed because the data spread around the diagonal line and follows the direction of the diagonal line so that it can be stated that the regression model fulfills the assumption of normality.

\section{Multicollinearity test}

The multicollinearity test aims to test whether the regression model found a correlation between independent or independent variables. A good regression model should not correlate with the independent variables. A common way to detect multicollinearity in this model is to look at R2 or stick to the tolerance and VIF values. The multicollinearity test can be done for the regression results of the two models to be estimated. The method is to find the tolerance number, where tolerance is the value 1-R2 R2. After the tolerance number is obtained, then the VIF number is searched. VIF (Variance Inflation Factor) number, which is the reciprocal of tolerance.

Table 4

Multicolinearias test results

\begin{tabular}{|c|c|c|c|c|c|}
\hline No & Variable & VIEW & & Cutt Off & Information \\
\hline 1 & Social Med & 1,553 & $<$ & 10 & $\mathrm{Mu}$ \\
\hline 2 & Face-to-Face Sales $\left(\mathrm{X}_{2}\right)$ & 1,553 & $\leq$ & 10 & Multicollinearity does not occur \\
\hline
\end{tabular}

Source: Processed from questionnaires, 2021

The table above shows that there is no multicollinearity between the independent variables because it shows a VIF value of less than 10 .

\section{Heteroscedasticity test}

It can be done by looking at the SPSS output on the scatterplot diagram to detect heteroscedasticity problems. The results of the heteroscedasticity test are illustrated in the following graph. 


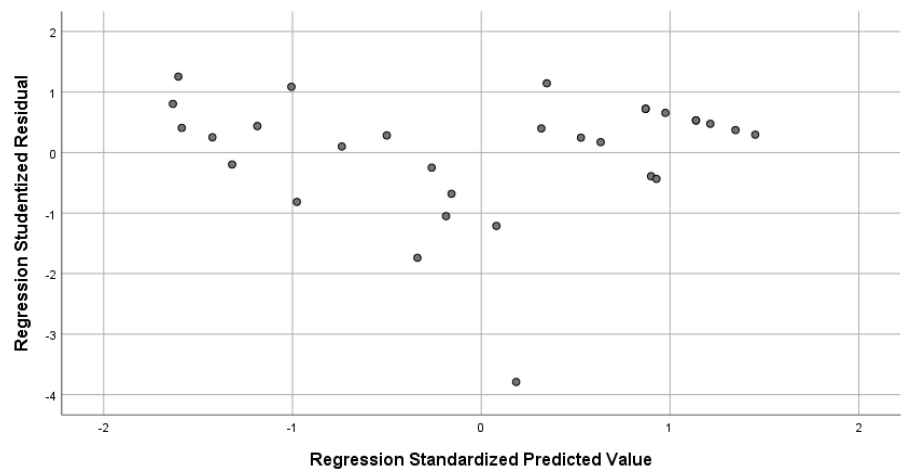

Figure 2. Scatterplot diagram to detect heteroscedasticity problems

The picture above shows that there is no heteroscedasticity because the spread of data forms a particular line or there is no clear pattern, and the points spread above and below the zero on the $\mathrm{Y}$-axis.

\section{Model feasibility test (F-Test)}

The results of the calculation of the F-test analysis are used to determine the effect of social media advertising variables (X1) and face-to-face sales (X2) on purchase intention (Y). The testing criteria include:

There is no significant effect if the probability level $\mathrm{F}(\operatorname{sig} \mathrm{F})>0.05$

It has a significant effect if the probability level F (sig F) $<0.05$.

Table 5

Results of model feasibility test (Test F)

\begin{tabular}{lccccc}
\hline \multicolumn{5}{c}{ ANOVA $^{\text {a }}$} \\
\hline Model & Sum of & & Mean & & \\
Squares & df & Square & F & Sig. \\
Regression & 121,516 & 2 & 60,758 & 7,462 &, $003^{\text {b }}$ \\
Residual & 219,851 & 27 & 8,143 & & \\
Total & 341,367 & 29 & & &
\end{tabular}

a. Dependent Variable: Purchase interest

b. Predictors: (Constant), Face to face sales, advertising

Data source: Processed from questionnaires, 2021

Based on the results in Table 4.9 above, it is known that the Fount value of 7.462 is more significant than Fable 3.34, so it can be concluded that the Advertising (X1), Face-to-Face Sales (X2) variables together have a significant effect on Purchase Interest (Y). This result is also reinforced by the significant value of the F test of 0.003 or sig 0.003 $<0.05$, which means that the Advertising (X1), Face-to-Face (X2) variables together have a significant effect on Purchase Intention (Y).

\section{Coefficient of Determination $\left(R^{2}\right)$}

The coefficient of determination (R2), in essence, measures how far the model's ability to explain the variation in the dependent variable. The coefficient of determination is between zero and one. A small R2 value means that the ability of the independent variables to explain the variation in the dependent variable is minimal. A value close to one means that the independent variables provide almost all the information needed to predict the variation in the dependent variable (Ghozali, 2018). 
Table 6

Result of Determination Coefficient Test (R2)

\begin{tabular}{|c|c|c|c|c|c|}
\hline \multicolumn{6}{|c|}{ Model Summary ${ }^{\mathrm{b}}$} \\
\hline Model & $\mathrm{R}$ & R Square & $\begin{array}{l}\text { Adjusted R } \\
\text { Square }\end{array}$ & & $\begin{array}{l}\text { Std. Error of the } \\
\text { Estimate }\end{array}$ \\
\hline 1 &, $597^{\mathrm{a}}$ & ,356 & & ,308 & 2,854 \\
\hline
\end{tabular}

a. Predictors: (Constant), Face to face sales, advertising

b. Dependent Variable: Purchase interest

Data source: Processed from questionnaires

The R square (R2) number is 0.356 or $35.6 \%$. This figure is used to see how the variables of social media advertising and face-to-face sales provide the information needed to explain buying interest in products being sold by $35.6 \%$; factors influence the rest. Other factors.

\section{Results of multiple linear regression analysis}

Regression analysis helps know the causal relationship that occurs between social media advertising variables (X1), face-to-face sales (X2), together on the purchase interest variable $(\mathrm{Y})$. The following is the result of the regression calculation.

Table 7

Multiple linear regression analysis test results

\begin{tabular}{|c|c|c|c|c|c|}
\hline \multicolumn{6}{|c|}{ Coefficients $^{\mathrm{a}}$} \\
\hline \multirow[b]{2}{*}{ Model } & \multicolumn{2}{|c|}{$\begin{array}{l}\text { Unstandardized } \\
\text { Coefficients }\end{array}$} & $\begin{array}{c}\text { Standardized } \\
\text { Coefficients }\end{array}$ & \multirow[b]{2}{*}{$\mathrm{t}$} & \multirow[b]{2}{*}{ Sig. } \\
\hline & $\mathrm{B}$ & Std. Error & Beta & & \\
\hline (Constant) & $-2,665$ & 7,511 & &,- 355 & ,725 \\
\hline Face to face sales &, 214 &, 241 & , 171 &, 889 & ,382 \\
\hline & ,487 &, 196 & ,478 & 2,486 & ,019 \\
\hline
\end{tabular}

a. Dependent Variable: Purchase interest

Data source: Processed from questionnaires

$$
\begin{gathered}
Y=a+b 1 \times 1+b 2 \times 2 \\
Y=-2,665+0,214 X 1+0,487 X 2
\end{gathered}
$$

Based on the results of the linear regression equation above, it can be seen that the constant value is negative 2,665, meaning that if all the independent variables are constant at 0 (zero), then buying Interest (variable $Y$ ) is negative. In other words, if social media advertising (X1) is worth 0 , and face-to-face selling (X2) is worth 0 , then buying Interest will be worth bad (minus). Furthermore, there is a positive influence between the independent variable face-to-face sales (X2) of 0.214; there is a positive influence between the advertising variable (X1) of 0.487 on the dependent variable of purchase intention $(\mathrm{Y})$.

\section{Hypothesis Test: t-test}

The hypothesis test used in this study is the partial test (t-test). The t-test means testing the regression coefficient partially (individually). This test is conducted to determine the individual significance between the independent and dependent variables by assuming that the other independent variables are considered constant. This test looks at whether the coefficient values obtained are actual or not between the t-count at the $5 \%$ confidence level or $\alpha=0.05$. The results of the t-test can be seen in Table 8 as follows. 
Table 8

Test Results for the Significance of Individual Parameters (t-test)

\begin{tabular}{|c|c|c|c|c|c|}
\hline \multirow[t]{2}{*}{ Model } & \multicolumn{2}{|c|}{$\begin{array}{l}\text { Coefficients } \\
\text { Unstandardized } \\
\text { Coefficients }\end{array}$} & \multirow{2}{*}{$\begin{array}{l}\text { Standardized } \\
\text { Coefficients } \\
\text { Beta } \\
\end{array}$} & \multirow[b]{2}{*}{$\mathrm{t}$} & \multirow[b]{2}{*}{ Sig. } \\
\hline & B & Std. Error & & & \\
\hline \multirow{3}{*}{$\begin{array}{ll}1 & \text { (Constant) } \\
& \text { Social Media Advertising }\end{array}$} & $-2,665$ & 7,511 & &,- 355 &, 725 \\
\hline & 487 & , 196 & ,478 & 2,486 & ,019 \\
\hline & ,214 & ,241 & ,171 & ,889 &, 382 \\
\hline
\end{tabular}

a. Dependent Variable: Interests Buy

Data source: Processed from questionnaires, 2021

Based on the results of the calculation of the t-test analysis in Table 4 above, it can be described as follows:

1) Social Media Advertising Variable (X1) has a beta value of 0.478 with a significant value of 0.019 , which is smaller than 0.05. This means that the Social Media Advertising variable has a significant effect on Buying Interest.

2) The face-to-face sales variable (X2) has a beta of 0.171 with a significance value of 0.382 , which is smaller than 0.05 . This means that the Face-to-Face Sales variable does not significantly affect Purchase Intention.

\section{Discussion of Research Results}

\section{The influence of social media advertising on purchase intention}

Social media advertising has a positive and significant impact on purchase intention. These findings provide the same results the following research from. Putri \& Lautania (2016), which support that social media advertising variables positively affect purchase interest. The results of the research that the advertising carried out has a relationship with buying Interest, this is following what is written in the book Impact of Social Media on Consumer Purchase Intention (Sharma \& Bhatt, 2018). The results show some practical implications for social media owners, how big is social advertising. The media can help increase trust and have a substantial impact on consumer buying interest. Messages that have attractiveness are used in an advertisement because advertisements have the purpose of conveying information to persuade, remind, and strengthen (Saladin, 2006).

\section{The effect of face-to-face sales on purchase intention}

Face-to-face sales have a positive effect on purchase intention. Although the results of the questionnaire data state several factors such as the seller's approach, familiarity, the orientation of the approach by Sales-Oriented and Customer-Oriented has an average value of 4.44 and is included in the "HIGHLY AGREE" category, in this study, the results show that the sales-oriented advance has a positive but not significant effect on the purchase intention variable. As research from Suhelmi (2018) states, face-to-face selling (personal selling) has a positive but insignificant effect on purchase intention. Many factors outside of this affect the level of significance of the face-toface variables. The WFH factor due to the covid-19 virus and the ease of ordering furniture via virtual media is thought to be the reason for the lack of significant face-to-face sales.

\section{Acknowledgments}

The author is grateful and thanks all those who have been very active in contributing to both thoughts and feedback from the beginning to the completion stage of our paper. Likewise, without funding assistance from the Ministry of Research and Technology, it seems that this paper would not have been possible for us to finish according to planning. So once again, we are grateful that our paper entitled "The Effect of Social Media Advertising and Face-toFace Sales on Purchase Intention for Customized Products (Case Study of Puncak Jaya Furniture): has received publication space. 


\section{References}

Alalwan, A. A., Rana, N. P., Dwivedi, Y. K., \& Algharabat, R. (2017). Social media in marketing: A review and analysis of the existing literature. Telematics and Informatics, 34(7), 1177-1190. https://doi.org/10.1016/j.tele.2017.05.008

Aldily, R. (2017). 101 Amazing Public Relation Ideas. Anak Hebat Indonesia.

De Vries, L., Gensler, S., \& Leeflang, P. S. (2012). Popularity of brand posts on brand fan pages: An investigation of the effects of social media marketing. Journal of interactive marketing, 26(2), 83-91. https://doi.org/10.1016/j.intmar.2012.01.003

Ghozali, I. (2018). Aplikasi analisis multivariete dengan program IBM SPSS 23.

Gibler, K., \& Nelson, S. (2003). Consumer behavior applications to real estate education. Journal of Real Estate Practice and Education, 6(1), 63-83.

Hasan, M. (2019). Social marketing: An Islamic perspective. Journal of Islamic Marketing.

Hausman, A. V., \& Siekpe, J. S. (2009). The effect of web interface features on consumer online purchase intentions. Journal of business research, 62(1), 5-13. https://doi.org/10.1016/j.jbusres.2008.01.018

Kotler, P. (2021). Manajemen pemasaran.

Lafferty, B. A., \& Goldsmith, R. E. (1999). Corporate credibility's role in consumers' attitudes and purchase intentions when a high versus a low credibility endorser is used in the ad. Journal of business research, 44(2), 109-116. https://doi.org/10.1016/S0148-2963(98)00002-2

Maxham III, J. G. (2001). Service recovery's influence on consumer satisfaction, positive word-of-mouth, and purchase intentions. Journal of business research, 54(1), 11-24. https://doi.org/10.1016/S0148-2963(00)00114-4

Prayitno, V. A. E. (2019). Factors Affecting Real Earnings Management. Emerging Markets: Business and Management Studies Journal, 6(2), 47-57.

Putri, C. L., \& Lautania, M. F. (2016). Pengaruh Capital Intensity Ratio, Inventory Intensity Ratio, Ownership Strucutre dan Profitability Terhadap Effective Tax Rate (ETR)(Studi pada Perusahaan Manufaktur yang Terdaftar di Bursa Efek Indonesia Tahun 2011-2014). Jurnal Ilmiah Mahasiswa Ekonomi Akuntansi, 1(1), 101-119.

Reily, M. (2018). Nielsen: Pembaca Media Digital Sudah Lampaui Media Cetak.

Saladin, D. (2006). Manajemen pemasaran. Edisi Keempat, Bandung: Linda Karya.

Schiffman, L. G., \& Kanuk, L. L. (2020). Perilaku konsumen.

Sharma, B. K., \& Bhatt, V. K. (2018). Impact of Social Media on Consumer Buying Behavior-A Descriptive Study on Tam Model. I-Manager's Journal on Management, 13(1), 34.

Solis, B., \& Breakenridge, D. K. (2009). Putting the public back in public relations: How social media is reinventing the aging business of $P R$. Ft Press.

Subawa, N. S., Widhiasthini, N. W., \& Suastika, N. P. M. W. S. (2020). The effect of experiential marketing, social media marketing, and brand trust on repurchase intention in Ovo applications. International Research Journal Of Management, IT And Social Sciences, 7(3), 11-21.

Suhelmi, D. (2018). Personal Selling Serta Pengaruhnya Terhadap Tingkat Kesadaran dan Minat Beli Calon Nasabah Asuransi Jiwasraya di Pekanbaru. Jurnal Tepak Manajemen Bisnis, 10(1), 25-41.

Sutisna. (2002). Perilaku konsumen dan komunikasi pemasaran.

Szolnoki, G., \& Hoffmann, D. (2013). Online, face-to-face and telephone surveys - Comparing different sampling methods in wine consumer research. Wine Economics and Policy,2(2), 57-66. https://doi.org/10.1016/j.wep.2013.10.001

Wahab, Z., Eka, D., \& Widiyanti, M. (2021). The Influences Of Promotion Mix On The Purchase Decision Of Daihatsu Xenia Car at PT. Astra Daihatsu International Tbk Palembang. Proceeding of International Conference on Family Business and Entrepreneurship.

Wang, X., Yu, C., \& Wei, Y. (2012). Social media peer communication and impacts on purchase intentions: A consumer socialization framework. Journal of interactive marketing, 26(4), 198-208. https://doi.org/10.1016/j.intmar.2011.11.004 